\title{
Research on the Influence of Early Experience on the Growth Rate of Science and Engineering Graduate Supervisors
}

\author{
Yu Xia* \\ Jilin University, Changchu, China \\ *Corresponding author: Yu Xia, $471289526 @ q q . c o m$
}

\begin{abstract}
This research is based on three northeastern double first-class polytechnic universities. A total of 1628 science and engineering graduate supervisors' resumes were referred to from an official website by the random sampling method, of which only 500 supervisors were included in consideration of complete information, key events, and time in terms of the educational background (undergraduate school, graduate school, doctoral school, number of masters, number for Dr.), early work background (number of postdocs, number of overseas visits, numbers of research work), and the growth rate (period from graduation to associate professor title). The higher education background and early work background were defined as early experience, and the database of these 500 science and engineering graduate supervisors with complete resume information from three double first-class universities in northeastern China was established. In this study, the growth rate of the growth period was divided into two at the critical period: the growth rate of the graduate supervisor to associate professors. Through stepwise multiple regression analysis, it was found that higher education background (undergraduate schools, graduate schools, doctoral schools, as well as the number of master's and doctorate degrees) as well as early work background (number of postdoctoral work, research work, and overseas visits) have a significant impact on the growth rate of graduate supervisors to associate professors.
\end{abstract}

Keywords: Graduate supervisors; Growth period; Growth rate; Early experience

Publication date: September 2021; Online publication: September 30, 2021

\section{Introduction}

In June 2010, the Central Committee of the Communist Party of China (CCCPC) and the State Council issued the Outline of the National Medium- and Long-Term Talent Development Plan (2010-2020), which supported the arrangements for talents by intensifying the training of talents and enhancing their attractiveness ${ }^{[1]}$. In 2012, with the approval of the Central Committee of the CPC and the State Council, 11 departments and units including the Organization Department of the CCCPC and the Ministry of Human Resources and Social Security jointly issued the National Special Support Plan for High-level Talents (hereinafter, referred to as the National Special Support Plan, also known as the Ten Thousand Personnel Plan), which is a support plan for high-level talents in China ${ }^{[2]}$. In March 2016, the CCCPC issued the Opinions on Deepening the Reform of the Talent Development System, aiming to change the backward institutional obstacles that constrain talent development as well as to eliminate obsolete ideas and concepts in order to form an internationally competitive talent development system.

Compared to the current rapid development of science and technology as well as the economic construction in China, the country still lacks high-level personnel without any good reference in terms of its training mode. Therefore, exploring the early experiences of graduate supervisors in three northeastern 
double first-class polytechnic universities in regard to their growth rate, the growth characteristics of a highlevel talented person, and the training methods, the advantage accumulation of talent growth can be further revealed.

\section{Concept definition}

Graduate supervisors would experience a growth process with several stages from a gestation period to a growth period, maturity period, and eventually a decline phase.

\section{Study design and hypothesis}

\subsection{Source of data}

In this research, the double first-class technology colleges and universities are based on three northeastern universities. A total of 1628 science and engineering supervisors' resumes were referred to from an official website by combining random sampling method, of which only 500 supervisors were included in consideration of complete information, key events, and time in terms of the educational background (undergraduate school, graduate school, doctoral school, number of masters, number for Dr.), early work background (number of postdocs, number of overseas visits, numbers of research work), and the growth rate (period from graduation to associate professor title). The database of 500 science and engineering graduate supervisors from three double first-class universities in northeastern China with complete resume information was then established.

\subsection{Data encoding}

Table 1. Related variables and operational definitions

\begin{tabular}{|c|c|c|c|}
\hline \multicolumn{2}{|c|}{ Dimension } & Indicators & Operational definition \\
\hline $\begin{array}{l}\text { Dependent } \\
\text { variable }\end{array}$ & $\begin{array}{c}\text { Growth rate } \\
\text { of associate } \\
\text { professor }\end{array}$ & \multicolumn{2}{|c|}{$\begin{array}{l}\text { The specific length of time from the highest doctoral degree to the rank of associate } \\
\text { professor is defined as the continuous data. }\end{array}$} \\
\hline \multirow[t]{2}{*}{$\begin{array}{l}\text { Independent } \\
\text { variables }\end{array}$} & $\begin{array}{c}\text { Higher } \\
\text { education } \\
\text { experience }\end{array}$ & Undergraduate school & $\begin{array}{l}\text { Undergraduate schools can be divided into two major categories, } \\
\text { which are domestic and foreign. The code for domestic double first- } \\
\text { class universities }=1 \text {; domestic universities }=2 \text {; domestic research } \\
\text { institutions }=3 \text {; foreign first-class universities }=4 \text { (top } 200 \\
\text { universities in the Quacquarelli Symonds (QS) Ranking); foreign } \\
\text { universities }=5 \text { (colleges or universities after the top } 200 \text { universities } \\
\text { in the QS ranking); foreign institutions }=6 \text {. }\end{array}$ \\
\hline & & Graduate school & $\begin{array}{l}\text { Graduate schools can be divided into two major categories, which } \\
\text { are domestic and foreign. The code for domestic double first-class } \\
\text { universities }=1 \text {; domestic universities }=2 \text {; domestic research } \\
\text { institutions }=3 \text {; foreign first-class universities }=4 \text { (top } 200 \\
\text { universities in the QS Ranking); foreign universities }=5 \text { (colleges or } \\
\text { universities after the top } 200 \text { universities in the QS Ranking); foreign } \\
\text { institutions }=6 .\end{array}$ \\
\hline
\end{tabular}

(Continued on the next page) 


\begin{tabular}{|c|c|c|}
\hline \multirow[t]{5}{*}{ Dimension } & Indicators & Operational definition \\
\hline & Doctoral school & $\begin{array}{l}\text { Doctoral schools are divided into domestic and foreign. The code for } \\
\text { domestic double first-class universities }=1 \text {; domestic universities }= \\
2 \text {; domestic research institutions }=3 \text {; foreign first-class universities } \\
=4 \text { (top } 200 \text { universities in the QS Ranking); foreign ordinary } \\
\text { universities = } 5 \text { (colleges or universities after the top } 200 \text { universities } \\
\text { in the QS Ranking); foreign research institutions }=6 \text {. }\end{array}$ \\
\hline & $\begin{array}{l}\text { Diversification of } \\
\text { higher education }\end{array}$ & $\begin{array}{l}\text { Repeat } 0 \text { times }=3 \text { (different school), repeat } 1 \text { time }=2 \text { (same } \\
\text { school), and repeat } 2 \text { times }=1 \text { (same school) are defined as the } \\
\text { number of categories. }\end{array}$ \\
\hline & Number of masters & The number of master's degrees is defined as the isometric data. \\
\hline & Number of Dr. & The number of doctoral degrees is defined as the isometric data. \\
\hline Early work & Number of postdocs & The number of postdoctoral work is defined as the isometric data. \\
\hline experience & $\begin{array}{c}\text { Number of overseas } \\
\text { visits }\end{array}$ & The number of overseas visits is defined as the isometric data. \\
\hline & Number of research & The number of research work is defined as the isometric data. \\
\hline \multirow[t]{2}{*}{ Control variables } & Gender & Male $=1 ;$ female $=2$ \\
\hline & Discipline & $\begin{array}{l}\text { Mathematical Science }=1 \text {, Chemical Science }=2 \text {, Earth Science }=3 \text {, } \\
\text { Life Sciences }=4 \text {, Medical Sciences }=6 \text {, and Information Sciences } \\
=7 \text {, are defined as the category variables. }\end{array}$ \\
\hline
\end{tabular}

\subsection{Research hypotheses}

(1) Hypothesis A: Higher education experience has a significant impact on the growth rate of talents becoming associate professors.

(2) Hypothesis A1: Talents with first-class bachelor's degree in China become associate professors at a faster rate.

(3) Hypothesis A2: Talents from foreign first-class graduate schools become associate professors at a faster rate.

(4) Hypothesis A3: Talents from doctoral foreign first-class schools become associate professors at a faster rate.

(5) Hypothesis A4: The more diverse the higher education background, the faster the growth rate of associate professors.

(6) Hypothesis A5: People with foreign higher education become associate professors more quickly than those with domestic higher education.

(7) Hypothesis B: Early work experience has a significant impact on the growth rate of talents becoming associate professors.

(8) Hypothesis B1: With postdoctoral experience, the growth rate of talents becoming associate professors is significantly affected.

(9) Hypothesis B2: Talents with more postdoctoral experience become associate professors faster.

(10) Hypothesis B3: People with early research experience become associate professors at a faster rate.

(11) Hypothesis B4: With overseas visiting experience, talents are able to become associate professors at a faster rate. 


\section{Data analysis}

The results of the stepwise regression analysis on the growth rate of associate professors influenced by early experience are shown in Table 2.

Table 2. Summary of stepwise regression analysis

\begin{tabular}{|c|c|c|c|c|c|c|c|}
\hline $\begin{array}{l}\text { Investment realization } \\
\text { sequence }\end{array}$ & $\begin{array}{l}\text { Multivariate } \\
\text { correlation } \\
\text { coefficient }\end{array}$ & $\begin{array}{l}\text { Coefficient of } \\
\text { determination, } \\
\mathrm{R}^{2}\end{array}$ & $\begin{array}{c}\text { Increase in } \\
\text { delta, } R^{2}\end{array}$ & $F$ value & $\begin{array}{l}\text { Net value } \\
\text { F delta F }\end{array}$ & $\begin{array}{l}\text { Unstandardized } \\
\text { beta, B }\end{array}$ & Beta \\
\hline Intercept & & & & & & 3.228 & \\
\hline Number of research work & $.142 \mathrm{a}$ & 020. & 020. & 10.302 & 10.302 & -.320 & -.155 \\
\hline $\begin{array}{l}\text { Graduated from a } \\
\text { domestic university with } \\
\text { a bachelor's degree }\end{array}$ & $.187 \mathrm{~b}$ & 035. & 015. & 8.996 & 7.555 & .434 & .115 \\
\hline $\begin{array}{l}\text { Studied at a foreign first- } \\
\text { class university for a } \\
\text { master's degree }\end{array}$ & $.211 \mathrm{c}$ & 045. & 010. & 7.728 & 5.044 & -.734 & -.099 \\
\hline
\end{tabular}

As shown in Table 2, among the multiple variables in this study, there are three variables that have significant predictive power for the growth rate of associate professors, which are the number of research work, graduated from a domestic university with a bachelor's degree, and studied at a foreign first-class university for a master's degree. The multivariate correlation coefficient of the three predictive variables and the growth rate of associate professors was 0.211 , the coefficient of determination, $\mathrm{R}^{2}$ was 0.045 , and the $\mathrm{F}$ value of the regression model integrity test was $7.72(p=0.00<0.05)$. Therefore, the three predictive variables can effectively explain a $4.5 \%$ variation of the growth rate of associate professors. In view of the predictive power of each variable, the most distinct explanatory for the growth rate of associate professors is the number of research work, in which the explanatory variance is $2 \%$. The predictive power of the other two independent variables (graduated from a domestic university with a bachelor's degree and studied in a foreign first-class university for a master's degree) is $1.5 \%$ and $1 \%$, respectively. From the standardized regression coefficient, the $\beta$ values of the three predictive variables in the regression model were -0.155 , 0.115 , and -0.099 , respectively. The negative $\beta$ values indicate a negative impact on the growth rate of associate professors, whereas the positive $\beta$ value indicates a positive impact on the growth rate of associate professors.

Using multiple linear regression, an equation is constructed as follows:

$$
\mathrm{Y}=\text { beta. } 0+\text { beta. } 1 \mathrm{X}_{1}+\ldots+\text { beta. } \mathrm{P} \mathrm{X}_{\mathrm{P}}+£
$$

$\mathrm{Y}$ is the dependent variable and is a random quantitative observed value; $\mathrm{X}_{1}, \mathrm{X}_{\mathrm{P}}$ is $\mathrm{P}$ independent variables; beta.o is a constant term; beta.1, beta.p is for partial regression coefficient; $£$ is for random error. $\mathrm{Y}$ cannot explain part of the variables in the change of the growth rate of associate professors as the dependent variable, with undergraduate school, graduate school, doctoral school, diversification of higher education, the number of master's and doctoral degrees, number of postdoctoral work, number of overseas visits, and the number of research work as independent variables. Four categorical variables including undergraduate school, graduate school, doctoral school, and diversification of higher education were transformed into dummy variables through virtualization processing; then, step-by-step multiple linear regression was carried out. The results of the regression are shown in the table. Three models were obtained 
by stepwise regression analysis. With the increase of explanatory variables in the included model, the fitting degree of the regression equation was continuously optimized, and the judgment coefficient of the final model, $\mathrm{R}^{2}$ was 0.045 , where both the overall $p$ value of this regression and the $p$ value of each variable were less than 0.001. In addition, the collinearity of the regression results was observed, the tolerance value was between 0.985 and 1, and the variance inflation factor (VIF) was less than the evaluation index value of 10. Both the characteristic root and the conditional index met the conditions. With that, the linear regression equation is obtained as follows:

$$
\mathrm{Y}=3.2280 .320 \mathrm{X}_{1}+0.434 \mathrm{X} 20.734 \mathrm{X}_{3}
$$

$\mathrm{X}_{1}, \mathrm{X}_{2}$, and $\mathrm{X}_{3}$ are the "number of research work," "graduated from a domestic university with a bachelor's degree," and "studied at a foreign first-class university for a master's degree," respectively. The validity of the regression equation and the autocorrelation of the residual sequence were tested, and a P-P plot was drawn. It was noted that the residual sequence presented a normal distribution. Therefore, the validity of the linear regression equation can be proved through experience, so hypotheses A1, A2, A5, B, and $\mathrm{B} 3$ are true, while those of $\mathrm{A} 3, \mathrm{~A} 4, \mathrm{~B} 1, \mathrm{~B} 2$, and $\mathrm{B} 4$ are not.

\section{Summary and suggestions}

\subsection{Influence of higher education experience on the growth rate of graduate supervisors}

In regard to higher education experience, both undergraduate schools and graduate schools have a significant impact on the growth rate of supervisors for master's in science and engineering program, but doctoral schools and the diversification of higher education have no significant impact on the growth rate of these supervisors. The level and type of undergraduate schools are important indicators for high-level talent selection ${ }^{[3]}$. It has been found that the level and type of undergraduate schools have a significant impact on the growth rate of these supervisors in becoming associate professors. The growth rate these supervisors who have graduated from double first-class universities in China in becoming associate professors is faster than that of the supervisors who have graduated from domestic ordinary universities ${ }^{[4]}$. The disparity of talent training quality and the education function between double first-class universities and colleges with ordinary universities in China are huge. Therefore, countries should pay more attention to the education quality of ordinary universities, promote the synchronous development of regular institutions of higher learning, increase investments for scientific research in ordinary colleges and universities, strengthen the guidance and provide a platform for students who are interested in academic profession, encourage students to actively take part in supervisor's topic, encourage the sharing of scientific research resources from double first-class colleges and universities with ordinary universities, as well as having the best students in ordinary colleges and universities to have an opportunity to come into contact with scientific research resources and platforms as soon as possible ${ }^{[5]}$.

In regard to the master's level of education, the level and type of graduate schools have a significant impact on the growth rate of associate professors in the growth period of science and engineering graduate supervisors. Graduate supervisors who studied in foreign first-class universities have a significant impact on the growth rate of associate professors. Therefore, the level and type of graduate schools have an earlier effect on the accumulation of advantages in the talent growth period ${ }^{[6]}$. In regard to doctoral education, the level and type of doctoral schools have no significant influence on the growth rate of associate professors in the growth period of science and engineering graduate supervisors. The diversification of higher education has no significant influence on the growth rate of associate professors with master's in science and engineering ${ }^{[7]}$. 


\subsection{Influence of early work experience on the growth rate of graduate supervisors}

In regard to early work experience of science and engineering graduate supervisors, the number of research work and postdoctoral work, as well as the number of overseas visits have a significant impact on the growth rate of science and engineering graduate supervisors ${ }^{[8]}$. The number of research work has a significant impact on the growth rate of Master of Science and Engineering (MSCT). The number of postdoctoral work has no significant effect on the growth rate of associate professors in the growth period. The number of overseas visits also has no significant influence on the growth rate of associate professors. In improving the quality of education in China, higher education international exchange should be strengthened, not only in terms of sending students abroad, but also to encourage young university teachers to increase their visiting projects abroad in order to learn scientific research work from a different perspective while gaining new train of thoughts and enlightening themselves with various scientific methods. In addition, it would also be beneficial to pay attention to scientific research personnel with early work experience, researchers, and Po after work, improve environment and domestic researchers, and Po after work ${ }^{[9]}$.

\section{Conclusion}

This research explored the growth rate of graduate supervisors from three northeastern double first-class polytechnic universities, revealed and summarized the general objectives, clarified the disciplines in the development of scientific research talents, explored the factors affecting the development of scientific research talents for high-end scientific research and talent management, as well as provided decisionmaking reference for relevant talent development plan ${ }^{[10]}$. The construction of a sustainable and healthy development of teachers in double first-class colleges and universities needs to be synchronized. Supervisors of early experience from three northeastern first-class technology universities were explored in this research to study the influence on growth rate in order to improve the team of graduate supervisors so as to better achieve professional development in science and engineering, provide relevant theoretical reference, as well as further achieve the goal of establishing double first-class colleges and universities.

\section{Disclosure statement}

The author declares that there is no conflict of interest.

\section{References}

[1] Qiao J, Chen X, Zhang, 2020, The Impact of Higher Education Experience, Early Work Experience, and First Paper on the "Dormant Period" of High-Level Talents. Degree and Graduate Education, (02): 44-53.

[2] Zhou J, Yan H, Sun Z, 2019, Research on Career Growth Trajectory and Influencing Factors of Chinese Researchers. Science Research Management, 40(10): 126-141.

[3] Zheng J, Wu W, 2019, The Development Characteristics and Educational Enlightenment of Potential Scientific and Creative Talents from the Perspective of Transcendent Education. Journal o Soochow University (Educational Science), 7(03): 75-82.

[4] Zhang J, Wang J, Zhou J, et al., 2019, Research in Science. Science, 37(02): 235-244.

[5] Wang R, 2019, Research on the Growth Law of Elite Talents from the Perspective of Talent Learning. Science and Education Guide (Late), (05): 138-139, 150. 
[6] Geng Q, Peng W, Wang Q, 2012, Research on the Quality Dimension of National Excellent Doctoral Dissertation Supervisors: Based on the Survey of 32 National Excellent Doctoral Dissertation Supervisors. China Higher Education Research, (01): 51-55.

[7] Wu S, 2019, Can Yangtze River Scholars Be Replicated - Discussion on the Research on the Growth Law of High-Level Talents in Education Discipline. Chongqing Higher Education Research, 7(01): 121-127.

[8] Zhang W, Chen R, Liu K, et al., 2018, A Study on the Development Characteristics of Science Foundation Supported Talents: A Case Study of Innovative Research Group Project Leaders. Science Foundation of China, 32(04): 382-386.

[9] Eggers WD, Hagel J, 2012, The Competitiveness of Brains - Talent, Policy, and the Future of American Competitiveness, Deloitte University Press, Atlanta.

[10] Yang S, 2012, Research on the Growth Law and Cultivation Strategy of Top Innovative Talents in Universities. China University of Geosciences. 